\title{
Membrane Protein Traffic
}

National Cancer Institute

\section{Source}

National Cancer Institute. Membrane Protein Traffic. NCI Thesaurus. Code C19429.

Posttranslational modification of proteins targeted for membranes. 